\title{
Effect of settlement on nutrition and health status of pastoral Gabra women of reproductive age in Kalacha Location, Marsabit County, Kenya
}

\author{
Amos Otieno Adongo 1,*, Bettina Shell-Duncan ${ }^{2}$ and J Prisca Tuitoek ${ }^{3}$ \\ 'Kenya Agricultural Research Institute, KARI Marsabit Research Centre, National Arid Land Research Centre, \\ Department of Food and Postharvest, Box 147, 60500 Marsabit, Kenya: ${ }^{2}$ Department of Anthropology, \\ University of Washington, Seattle, WA, USA: ${ }^{3}$ Department of Human Nutrition, Egerton University, Nioro, Kenya
}

Submitted 14 February 2012: Final revision received 23 September 2012: Accepted 11 October 2012: First published online 7 December 2012

\begin{abstract}
Objective: The objective of the present study was to evaluate the effect of settlement on the nutrition and health status of pastoral women of reproductive age.

Design: A cross-sectional survey that included a $24 \mathrm{~h}$ dietary recall was administered to 224 randomly selected Gabra women. Height and weight were used to compute BMI. Whole capillary blood was used to measure Hb. Additional capillary blood was collected on filter paper and dried blood spots were analysed for transferritin receptor, C-reactive protein and $\alpha_{1}$-acid glycoprotein. Descriptive statistics were used to analyse population characteristics. The $t$ test and the $\chi^{2}$ test were used to determine population differences. Multiple criteria models were used to determine the prevalence of Fe deficiency, anaemia and inflammation. Setting: Settled and semi-settled women in Kalacha Location in Marsabit County, Kenya.

Subject: Non-pregnant women aged 15-49 years.

Results: Fe repletion was observed in $43 \%$ of settled and $40 \%$ of semi-settled women. Fe-deficiency erythropoiesis in was found in $18 \%$ of settled and $20 \%$ of semi-settled women, whereas $15 \%$ of settled compared with $25 \%$ of semi-settled women were suffering from Fe-deficiency anaemia. Anaemia due to chronic diseases was more prevalent in semi-settled women than in settled women, and more common than Fe-deficiency anaemia.

Conclusions: Settled women were significantly less anaemic than semi-settled women, but had similarly high levels of chronic energy deficiency. While anaemia and Fe deficiency were more pronounced in semi-settled than settled women, anaemia of chronic disease and chronic infection were highly prevalent in both communities. Policies should be put in place to improve overall nutrition among pastoral women.
\end{abstract}

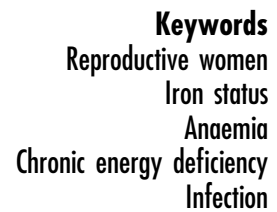

Keywords

ron status

deficiency

Infection
African pastoralists are currently facing challenges such as frequent droughts and floods, as well as high poverty levels ${ }^{(1)}$. These factors have further been exacerbated by government policy frameworks that promote sedentary livelihood systems. Sedentarization is a process where pastoralists shift from nomadic or semi-nomadic livestock production to permanent settlement and adopt new livelihoods through agriculture, trade, or part- and fulltime urban occupation ${ }^{(2)}$. While intended to promote improved health and nutrition through market integration and access to health care, the result is high population pressure in permanent settlements, political insecurity and economic stratification, leading to settled and semisettled households, especially in rangeland areas ${ }^{(3)}$. A change from nomadic to sedentary lifestyle has been observed among the Fulani in West Africa, who keep livestock as well as practise limited cultivation during their migration ${ }^{(4)}$.

In Marsabit County, Kenya, frequent droughts have pushed many members of the Gabra community out of traditional livestock monoculture ${ }^{(5)}$. In addition, increased population pressure has led to settlement around the water points, which also act as trading centres and relief food distribution points ${ }^{(6)}$. This kind of settlement has resulted in rapid changes in food availability as well as food preferences ${ }^{(1)}$. Generally, 59 to $64 \%$ of communities living in marginal areas of Marsabit County, especially in Maikona Division, are considered food poor $^{(5)}$. The result of this is high vulnerability to malnutrition among women who are left in the settlement to 
care for children and the aged ${ }^{(7)}$. Currently, most arid and semi-arid land (ASAL) policies in Kenya encourage sedentism as a solution to food insecurity ${ }^{(8)}$. However, a study conducted in Marsabit County showed dietary inadequacies among settled Rendille women ${ }^{(9)}$. Currently, there are limited data on dietary intake, Fe deficiency, anaemia and infection among Gabra women in both settled and semi-settled households. Neither the Kenya Demographic and Health Surveys ${ }^{(10,11)}$ nor the Kenya National Micronutrient Survey ${ }^{(12)}$ covered Marsabit District.

The objective of the present study was to evaluate the effect of settlement on the nutrition and health status (Fe deficiency and anaemia) of pastoralist Gabra women of reproductive age. We tested the hypothesis that there are no differences in dietary intake, body composition, Fe status and infection between settled and semi-settled Gabra women. Understanding women's health and nutrition is significant because its consequences affect both the woman and her infants ${ }^{(13)}$. Gabra women have high maternal mortality rate, currently estimated at 599/100 000 live births compared with the national estimate of 590/100 000 live births ${ }^{(14)}$, that may be influenced by nutritional status. The study results may assist policy makers in designing food programmes and nutrition and health interventions suited to pastoral conditions in northern Kenya.

\section{Materials and methods}

\section{Design and study population}

A cross-sectional survey was conducted among settled and semi-settled Gabra women in Kalacha Location in northern Kenya. The study excluded women younger than 15 years and older than 49 years, as well as pregnant women and women with clinically acute or chronic illness due to infection or inflammation.

\section{Sampling procedure}

A systematic sampling method described by Mugenda and Mugenda ${ }^{(15)}$ was used in which a sampling interval of four was found by dividing the total number of households by the sample size of each settlement. Starting with respondent number four and skipping every four names, 224 women (140 settled and eighty-four semi-settled women) aged 15-49 years were recruited. Only one adult woman was selected per household for administration of the survey instruments after giving consent. The consent was translated into the local Gabra language and was read to the respondents, who were asked to provide oral consent. One hundred women gave consent to blood sampling. One blood sample was smudged and consequently discarded, leaving ninety-nine samples (forty-one from settled and fifty-eight from semi-settled women). Blood sample size was low because some women declined to give blood due to fear they would be tested for HIV, despite the fact that the consent form stated this test would not be conducted. However, the sample size achieved for biochemical evaluation was above one-third of the overall sample size required to make generalizations of a population, as reported in the 1999 micronutrient survey in Kenya ${ }^{(12)}$.

\section{Questionnaire}

Information on marital status, age, household size, education levels, livestock numbers and income levels (in Kenya shillings (KES), categorized as $1=\mathrm{KES}$ 101-1000, $2=$ KES 1001-2000, $3=$ KES 2001-5000, $4=$ KES 5001-10000 and 5= KES >10 001) was collected by the first author using a structured questionnaire. The dependency ratio was calculated by dividing the total number of household members by the number of employed members of the household. Livestock numbers were converted into Tropical Livestock Units (TLU) following the method of Fujita et $a l^{(3)}$. A $24 \mathrm{~h}$ dietary recall was conducted to estimate nutrient intake following methods used by Maruapula and Chapman-Novakofski ${ }^{(16)}$. This allowed us to test the hypothesis of no difference in nutrient intake between settled and semi-settled women. Food estimation and conversion into actual weights were done according to Gibson and Ferguson ${ }^{(17)}$. Volumes of local household utensils such glasses, cups, plates and spoons were measured using a measuring cup graduated both for weights and volumes. To convert to actual measurements for analysis purposes, the volume of water equivalent to the volume of the actual free-flowing food or drink was measured using a measuring cylinder, and then converted into weight equivalents of the actual food or beverage consumed (1 litre was assumed to be equivalent to $1 \mathrm{~kg}$ for free-flowing food). Mixed foods, especially githeri (dry maize mixed with beans then cooked), whose ingredients could not be quantified during the survey were later cooked in the mixing ratio reported by respondents. The study revealed three mixing ratios (beans to maize) in Kalacha, namely 1:0.75; $1: 0 \cdot 5$ and $1: 1$. In each cooked ratio, three scoops of a standard measuring cup were randomly made with thorough mixing after every scoop. The beans and maize were separated and their weights determined using a digital scale (model BA3105; Sartorius AG, Gottingen, Germany). Graduated food models made from rubber sponge borrowed from the Department of Nutrition at Egerton University were used to estimate the weight of solid foods. The results were then compared with nutrient standards provided in the Nutrisurvey program ${ }^{(18)}$ and the Kenya Food Composition Tables ${ }^{(19)}$.

\section{Antbropometric assessment}

Weight of the women was measured to the nearest $0 \cdot 1 \mathrm{~kg}$ using a SECA scale (model 7621019009; SECA, Hamburg, Germany). Height was measured by use of a locally improvised stadiometer to the nearest $1.0 \mathrm{~mm}^{(20)}$. 


\section{Blood sampling and biochemical analysis}

The blood sampling was conducted by a qualified clinical officer from Marsabit District Hospital and was supervised by the lead author. To conduct this procedure, a puncture site on the left ring finger or middle finger was disinfected using methylated spirit. The ring finger was pricked using a sterile disposable lancet, and the first drop was discarded $^{(21)}$. The second drop was filled into a micro cuvette by capillary action, then placed in a HemoCue ${ }^{\circledR}$ analyser (model 0402012008; HemoCue AB, Angelholm, Sweden) for $15 \mathrm{~s}$ and readings taken. The instrument was calibrated daily. Two more drops of whole free-flowing capillary blood were collected onto a standardized filter paper (903; Whatman catalogue no. 10534612), allowed to dry for $3-4 \mathrm{~h}$ and then stored frozen at $-20^{\circ} \mathrm{C}^{(22,23)}$. Dried blood spots (DBS) were analysed for C-reactive protein (CRP), an acute-phase protein that indicates recent infection, and transferrin receptor (TfR) using enzyme-linked immunoassay following the method of Brindle et $a l .^{(24)}$ that has previously been validated by McDade and Shell-Duncan ${ }^{(25)}$ and Shell-Duncan and McDade ${ }^{(23)}$. TfR is a sensitive indicator of Fe status that is not influenced by infection ${ }^{(21)}$. $\alpha_{1}$-Acid glycoprotein (AGP), also called orosomucoid, which provides a measure of chronic infection, was measured from DBS using an enzyme immunoassay kit (GenWay catalog no. 40-28822927F; BioTek Instruments Inc., Winooski, VT, USA) as validated by Brindle et al. ${ }^{(26)}$.

\section{Data analysis}

Data were analysed using the SPSS statistical software package version 12 and results presented as frequencies, means and standard deviations. The $t$ test and the $\chi^{2}$ test were used to determine population differences. Confidence level was set at $95 \%$ for all analyses $(P \leq 0 \cdot 05)$. The Nutrisurvey for Windows program ${ }^{(18)}$ was used to analyse nutrient intakes and the results were compared with Recommended Nutrient Intakes (RNI) ${ }^{(27)}$ and the Kenya Food Composition Table ${ }^{(20)}$. BMI was calculated as weight in kilograms divided by the square of height in metres ${ }^{(28)}$ and used to classify chronic energy deficiency (CED) using the cut-off values established by Ferro-Luzzi et al. ${ }^{\text {(29) }}$.

An $\mathrm{Hb}$ value of $<12 \mathrm{mg} / \mathrm{dl}$ was considered anaemic ${ }^{(22)}$. Established cut-off values for biochemical markers of Fe and inflammation in DBS were used to identify women with abnormal values: TfR $>5.0 \mathrm{mg} / \mathrm{l}, \mathrm{AGP}>1.0 \mathrm{~g} / \mathrm{l}$ and $\mathrm{CRP}>2.0 \mathrm{mg} / \mathrm{l}$. TfR, which is a sensitive indicator of Fe status, has been found to be capable of detecting Fe deficiency in the presence of anaemia (Fe-deficiency anaemia (IDA)) as well as pre-anaemic Fe deficiency (Fe-deficiency erythropoiesis (IDE) $)^{(30)}$. It was therefore possible to identify women who were Fe replete, and those with IDE, with IDA and with anaemia caused by a non-specific immune response to infection involving Fe sequestration, i.e. anaemia of chronic disease (ACD). This was done using the multiple criteria model, based on having two or more of the four Fe status indices outside the cut-off values ${ }^{(31,32)}$. Fe replete was defined as normal $\mathrm{Hb}(<12 \mathrm{mg} / \mathrm{dl})$, normal TfR $(<5 \cdot 0 \mathrm{mg} / \mathrm{l})$ and normal CRP $(<2 \cdot 0 \mathrm{mg} / \mathrm{l}) / \mathrm{AGP}(<1 \cdot 0 \mathrm{~g} / \mathrm{l})$. IDE was defined as normal $\mathrm{Hb}$ and elevated TfR. IDA was defined as low $\mathrm{Hb}$ and elevated TfR, whereas ACD was defined as low $\mathrm{Hb}$, normal TfR, elevated CRP and/or $\mathrm{AGP}^{(32)}$. CRP is an indicator of acute infection, increasing and reaching a maximum $24 \mathrm{~h}$ after the initial infection occurs ${ }^{(32)}$. AGP indicates the presence of chronic infection, reaching a maximum between 2 and $5 \mathrm{~d}$; because it rises and declines more slowly than CRP it provides information about recent illness as well. Combined measures of these acute-phase proteins, as outlined by Thurnham and Northrop-Clewes ${ }^{(33)}$, were used to classify the illness of individuals as follows: (i) healthy, no raised acute-phase proteins; (ii) chronic illness, raised AGP only; (iii) current infection, raised CRP and raised AGP; and (iv) recently ill (acute), raised CRP with normal AGP.

\section{Etbical approval}

Ethical approval was obtained from the Kenya Medical Research Institute/National Review and Ethics Committee and Institutional Review Boards of the University of Washington.

\section{Results}

\section{Population characteristics}

Table 1 summarizes the characteristics of the study population. The mean age of settled women was significantly $(P=0.024)$ higher than that of semi-settled women. A significantly $(P=0 \cdot 043)$ higher number of semi-settled women were married compared with settled women. There were more widows in settled households than in semi-settled households. About $4 \cdot 3 \%$ of women in settled households were either divorced or separated compared with none of the semi-settled women. This could have been one of the major determinants of sedentarization, since mothers with no livestock have to rely on relief food for livelihood sustenance. The main religions were Christian, Islam and traditional. Education standards were low. The majority of semi-settled women had significantly $(P=0.003)$ lower formal education attendance than their settled counterparts. The mean TLU was significantly $(P<0.001)$ higher in semi-settled households than in settled households although it had no correlation with nutritional status. There were significant $(P=0 \cdot 054)$ differences in household income, with the majority falling in the income range of KES 101-1000 (\$US $1=$ KES 84), mainly from sale of their livestock. The mean BMI of settled women was not significantly different $(P=0 \cdot 168)$ from that of semi-settled women (Table 1$)$. Interestingly, for the ninety-nine women who were evaluated for Fe status, BMI was significantly $(P=0 \cdot 028$; 
Table 1 Characteristics of the study population: pastoral Gabra women of reproductive age, Kalacha Location in Marsabit District, Kenya

\begin{tabular}{|c|c|c|c|c|c|}
\hline \multirow[b]{2}{*}{ Variable } & \multicolumn{2}{|c|}{$\begin{array}{l}\text { Settled } \\
(n 140)\end{array}$} & \multicolumn{2}{|c|}{$\begin{array}{l}\text { Semi-settled } \\
(n \text { 84) }\end{array}$} & \multirow[b]{2}{*}{$P$ value $(t$ test } \\
\hline & Mean & SD & Mean & SD & \\
\hline Age (years) & $33 \cdot 2$ & $9 \cdot 0$ & $30 \cdot 3$ & $9 \cdot 5$ & 0.024 \\
\hline BMl $\left(\mathrm{kg} / \mathrm{m}^{2}\right)$ & $19 \cdot 3$ & $3 \cdot 2$ & $18 \cdot 7$ & $2 \cdot 8$ & $0 \cdot 168$ \\
\hline No. of household members & $5 \cdot 1$ & $1 \cdot 9$ & $5 \cdot 0$ & $1 \cdot 7$ & 0.418 \\
\hline No. of employed household members & 0.2 & 0.5 & $0 \cdot 1$ & $0 \cdot 2$ & $<0.001$ \\
\hline Dependency ratio & $4 \cdot 5$ & $2 \cdot 2$ & $5 \cdot 0$ & $1 \cdot 8$ & 0.673 \\
\hline \multirow[t]{2}{*}{ TLU } & $4 \cdot 8$ & $5 \cdot 8$ & $10 \cdot 7$ & $8 \cdot 9$ & $<0.001$ \\
\hline & \multicolumn{2}{|c|}{$\%$} & \multicolumn{2}{|c|}{$\%$} & $\left(\chi^{2}\right.$ test $)$ \\
\hline \multicolumn{6}{|l|}{ Household income category } \\
\hline $1=$ KES $101-1000$ & \multicolumn{2}{|c|}{$22 \cdot 6$} & \multicolumn{2}{|c|}{$15 \cdot 7$} & 0.054 \\
\hline $2=$ KES 1001-2000 & \multirow{2}{*}{\multicolumn{2}{|c|}{$\begin{array}{r}6 \cdot 0 \\
14 \cdot 7\end{array}$}} & \multicolumn{2}{|c|}{0.5} & \\
\hline $3=$ KES 2001-5000 & & & \multicolumn{2}{|c|}{$10 \cdot 6$} & \\
\hline $4=$ KES 5001-10000 & \multicolumn{2}{|c|}{$13 \cdot 4$} & \multicolumn{2}{|c|}{$\begin{array}{l}6 \cdot 5 \\
5 \cdot 5\end{array}$} & \\
\hline $5=\mathrm{KES}>10001$ & \multicolumn{2}{|c|}{$4 \cdot 6$} & & & \\
\hline \multicolumn{6}{|l|}{ Marital status } \\
\hline Married & \multicolumn{2}{|c|}{$84 \cdot 3$} & \multicolumn{2}{|c|}{$95 \cdot 2$} & 0.043 \\
\hline Widow & \multicolumn{2}{|c|}{$11 \cdot 4$} & \multicolumn{2}{|c|}{$4 \cdot 8$} & \\
\hline Divorced/separated & \multicolumn{2}{|c|}{$4 \cdot 3$} & \multicolumn{2}{|c|}{-} & \\
\hline Occupation & & & & & 0.008 \\
\hline Livestock & \multicolumn{2}{|c|}{$11 \cdot 4$} & \multicolumn{2}{|c|}{$7 \cdot 1$} & \\
\hline Housewife & \multicolumn{2}{|c|}{$75 \cdot 7$} & \multicolumn{2}{|c|}{$92 \cdot 9$} & \\
\hline Casual labour & \multicolumn{2}{|c|}{$4 \cdot 3$} & \multicolumn{2}{|c|}{-} & \\
\hline Business & & & & & \\
\hline Salaried & & & & & \\
\hline Education & & & & & 0.003 \\
\hline Post primary & & & & & \\
\hline Primary & & & & & \\
\hline Adult literacy & & & & & \\
\hline None & & & & & \\
\hline Religion & & & & & 0.016 \\
\hline Christian & & & & & \\
\hline Islamic & & & & & \\
\hline Traditional & & & & & \\
\hline
\end{tabular}

TLU, Tropical Livestock Units; KES, Kenyan shillings (\$US 1 = KES 84).

two-tailed) higher among settled women $\left(19 \cdot 5 \mathrm{~kg} / \mathrm{m}^{2}\right)$ than among semi-settled women $\left(18 \cdot 2 \mathrm{~kg} / \mathrm{m}^{2}\right)$. Table 2 gives a summary of classification of the respondents based on CED. The prevalence of CED varied little between women in settled and semi-settled households (49\% v. 52\%, respectively).

\section{Nutrient intakes from $24 \mathrm{~b}$ dietary recall}

Table 3 summarizes nutrient intakes from the $24 \mathrm{~h}$ dietary intakes survey. Mean energy intake was significantly $(P<0 \cdot 001)$ higher among the settled women compared with their semi-settled counterparts. The high mean energy intake observed in settled households could be due to easy access to both purchased and relief foods. Settled women also had easy access to shops and cereal grinding mills that offer a variety of foods in terms of carbohydrate types, compared with semi-settled women. However, the high levels of CED suggest that these high intakes may not be typical. Means also do not reflect variation, and it is useful therefore to also examine the percentages who met nutritional adequacy (Table 4). Significantly more settled women met the RNI for energy
$(P<0 \cdot 001)$, but overall a substantial number of women in both communities did not meet the RNI for energy. The mean protein intake was also significantly $(P=0 \cdot 005)$ higher for settled women compared with semi-settled women and significantly $(P=0 \cdot 012)$ more of the former met the RNI for protein ${ }^{(34)}$. The major food sources of protein were beans, peas, meat and milk. Low protein intake may be explained by a lack of milk due to prevailing drought. Significant differences were observed in Fe intake $(P<0 \cdot 001)$ between settled and semi-settled women, although intake in both groups fell substantially below the RNI. Vitamin C, which enhances the absorption of non-haem forms of $\mathrm{Fe}$ found in plant foods, was also very low in the diets of both groups of women, attributable to a lack of vegetables and fruits in the diets of most women. Finally, the dietary intake of vitamin A, which also influences Fe metabolism, was not significantly different between women from the two communities, but substantially lower than the RNI. Overall, the micronutrient intakes of many Gabra women were below the $\mathrm{RNI}^{(27)}$, as found previously in Rendille women in Marsabit ${ }^{(9)}$ and nationally in Kenya ${ }^{(35)}$. 
Table 2 Prevalence (\%) of different grades of CED and obesity: comparison of the study population (pastoral Gabra women of reproductive age, Kalacha Location in Marsabit District, Kenya) with other women

\begin{tabular}{|c|c|c|c|c|c|c|}
\hline \multirow[b]{2}{*}{ Population } & \multicolumn{4}{|c|}{ CED } & \multirow[b]{2}{*}{ Normal weight } & \multirow[b]{2}{*}{ Overweigh } \\
\hline & Grade III & Grade II & Grade I & Total (Grade III-I) & & \\
\hline \multicolumn{7}{|l|}{ Gabra women } \\
\hline Settled & $10 \cdot 7$ & $8 \cdot 6$ & $29 \cdot 3$ & $48 \cdot 6$ & $46 \cdot 4$ & $5 \cdot 0$ \\
\hline Semi-settled & $8 \cdot 3$ & $14 \cdot 3$ & $29 \cdot 8$ & $52 \cdot 4$ & $45 \cdot 2$ & $2 \cdot 4$ \\
\hline \multicolumn{7}{|l|}{ Rendille ${ }^{(9)}$} \\
\hline Nomads & $2 \cdot 9$ & $5 \cdot 8$ & $35 \cdot 0$ & $43 \cdot 7$ & $54 \cdot 4$ & $1 \cdot 9$ \\
\hline Korr & $4 \cdot 7$ & $7 \cdot 8$ & $36 \cdot 5$ & $49 \cdot 0$ & $50 \cdot 5$ & 0.5 \\
\hline Karare & $4 \cdot 3$ & $8 \cdot 0$ & $31 \cdot 6$ & $43 \cdot 9$ & $53 \cdot 5$ & $2 \cdot 7$ \\
\hline Songa & $6 \cdot 7$ & $11 \cdot 7$ & $33 \cdot 7$ & $52 \cdot 1$ & $45 \cdot 4$ & $2 \cdot 5$ \\
\hline Marsabit & $5 \cdot 0$ & $2 \cdot 5$ & $25 \cdot 6$ & $33 \cdot 1$ & $61 \cdot 2$ & $5 \cdot 8$ \\
\hline India*(9) & $16 \cdot 0$ & $24 \cdot 0$ & $28 \cdot 0$ & $68 \cdot 0$ & $31 \cdot 0$ & $1 \cdot 0$ \\
\hline Ethiopia $^{(9)}$ & $6 \cdot 0$ & $15 \cdot 0$ & $37 \cdot 0$ & $58 \cdot 0$ & $42 \cdot 0$ & 0.07 \\
\hline Zimbabwe $^{\star(9)}$ & $2 \cdot 0$ & $5 \cdot 0$ & $19 \cdot 0$ & $26 \cdot 0$ & $61 \cdot 0$ & $14 \cdot 0$ \\
\hline
\end{tabular}

CED, chronic energy deficiency.

CED based on BMI range ${ }^{(29)}$ : severe (Grade III), BMI < 16.00 kg/m²; moderate (Grade II), BMI = 16.00-16.99 kg/m²; mild $(\mathrm{Grade} \mathrm{I}), \mathrm{BMI}=17 \cdot 00-18 \cdot 49 \mathrm{~kg} / \mathrm{m}^{2}$. *Lowest class in terms of social status.

Table 3 Mean daily nutrient intakes according to settlement status: pastoral Gabra women of reproductive age, Kalacha Location in Marsabit District, Kenya

\begin{tabular}{|c|c|c|c|c|c|c|}
\hline \multirow[b]{2}{*}{ Nutrient } & \multicolumn{2}{|c|}{$\begin{array}{l}\text { Settled } \\
(n \text { 140) }\end{array}$} & \multicolumn{2}{|c|}{$\begin{array}{l}\text { Semi-settled } \\
(n 84)\end{array}$} & \multirow[b]{2}{*}{$\mathrm{RNI}^{(27)}$} & \multirow{2}{*}{$\begin{array}{l}P \text { value } \\
(t \text { test })\end{array}$} \\
\hline & Mean & SD & Mean & SD & & \\
\hline Energy $\left(\mathrm{kJ}^{\star}\right)$ & 7868 & 2848 & 6400 & $2817 \cdot 4$ & 9247 & $<0.001$ \\
\hline Protein $(\mathrm{g})$ & $59 \cdot 2$ & $33 \cdot 0$ & $46 \cdot 1$ & 34.9 & $49-56$ & 0.005 \\
\hline Fat $(\mathrm{g})$ & $53 \cdot \overline{9}$ & 31.5 & $48 \cdot 0$ & $26 \cdot 6$ & $37-86$ & 0.146 \\
\hline Carbohydrate (g) & $304 \cdot 8$ & $114 \cdot 1$ & $243 \cdot 8$ & $111 \cdot 9$ & 160 & $<0.001$ \\
\hline Vitamin A $(\mu \mathrm{q})$ & $116 \cdot 4$ & $88 \cdot 7$ & $134 \cdot 2$ & $123 \cdot 3$ & 500 & 0.212 \\
\hline Total folate $(\mathrm{mg})$ & $249 \cdot 6$ & $136 \cdot 3$ & $194 \cdot 1$ & 128.5 & 400 & 0.003 \\
\hline Vitamin C (mg) & $9 \cdot 5$ & $15 \cdot 8$ & $6 \cdot 3$ & $9 \cdot 3$ & 45 & 0.092 \\
\hline $\mathrm{Fe}(\mathrm{mg})$ & 13 & $5 \cdot 4$ & 10 & $5 \cdot 0$ & $20-59$ & $<0.001$ \\
\hline
\end{tabular}

RNI, Recommended Nutrient Intake.

${ }^{*} 1 \mathrm{kcal}=4 \cdot 184 \mathrm{~kJ}$.

Table 4 Prevalence (\%) of nutrient adequacy overall and according to settlement status: pastoral Gabra women of reproductive age, Kalacha Location in Marsabit District, Kenya

\begin{tabular}{|c|c|c|c|c|}
\hline Nutrient & $\begin{array}{l}\text { Overall } \\
(n \text { 224) }\end{array}$ & $\begin{array}{l}\text { Settled } \\
(n 140)\end{array}$ & $\begin{array}{l}\text { Semi-settled } \\
(n \text { 84) }\end{array}$ & $\begin{array}{l}P \text { value } \\
(t \text { test })\end{array}$ \\
\hline Energy (kJ) & $24 \cdot 0$ & $29 \cdot 3$ & $16 \cdot 7$ & $<0.001$ \\
\hline Protein $(\mathrm{g})$ & $46 \cdot 0$ & $54 \cdot 3$ & $32 \cdot 1$ & 0.012 \\
\hline Fat $(\mathrm{g})$ & $64 \cdot 7$ & $69 \cdot 3$ & $57 \cdot 1$ & $<0.001$ \\
\hline Vitamin $A(\mu \mathrm{g})$ & 0.9 & 0.7 & 1.2 & 0.88 \\
\hline Total folate (mg) & $64 \cdot 7$ & $71 \cdot 4$ & $53 \cdot 6$ & $<0.001$ \\
\hline Vitamin C (mg) & $1 \cdot 8$ & $2 \cdot 1$ & $1 \cdot 2$ & 0.057 \\
\hline $\mathrm{Mg}(\mathrm{mg})$ & $80 \cdot 8$ & $87 \cdot 1$ & $70 \cdot 2$ & $<0.001$ \\
\hline $\mathrm{Fe}(\mathrm{mg})$ & $8 \cdot 0$ & $10 \cdot 7$ & $3 \cdot 6$ & $<0.001$ \\
\hline
\end{tabular}

\section{Biochemical status of iron and infection among settled and semi-settled Gabra women}

Table 5 summarizes the results of biochemical analyses of blood samples. Mean $\mathrm{Hb}$ was significantly $(P=0 \cdot 043)$ higher among settled women than among semi-settled women. The prevalence of anaemia was 39\% among settled women and $60 \%$ among semi-settled women. There were no significant differences in mean TfR $(P=0.062), \operatorname{CRP}(P=0.319)$ and AGP $(P=0.584)$ between settled and semi-settled women. Overall, $43 \%$ of the
Gabra women presented with elevated TfR, indicating Fe deficiency. Of the women in settled and semi-settled households, $68 \%$ and $48 \%$ respectively had normal TfR.

\section{Biochemical assessment of illness}

Combined measures of acute-phase proteins, as outlined by Thurnham and Northrop-Clewes ${ }^{(33)}$, were used to classify the illness of Gabra women (Fig. 1). Only $59 \%$ of settled and $46 \%$ of semi-settled women were classified as healthy (no raised acute-phase proteins). Chronic illness (raised AGP only) was the most common type of illness among Gabra women and more common among semi-settled (41\%) than settled women (29\%). However, more settled (7.3\%) than semi-settled (5.2\%) women were identified as having a current infection (raised CRP and raised AGP). About 7\% and $5 \%$ of semi-settled and settled women respectively were found to be recently ill (raised CRP with normal AGP).

\section{Multiple criteria model to estimate overall prevalences of anaemia in settled and semi-settled Gabra women}

Figure 2 gives the percentages of women falling into the various categories of anaemia. Using the multiple criteria 
Table 5 Results of biochemical analysis of blood samples overall and according to settlement status: pastoral Gabra women of reproductive age, Kalacha Location in Marsabit District, Kenya

\begin{tabular}{|c|c|c|c|c|}
\hline Fe and inflammation indices & $\begin{array}{l}\text { Overall } \\
(n 99)\end{array}$ & $\begin{array}{l}\text { Settled } \\
(n 41)\end{array}$ & $\begin{array}{l}\text { Semi-settled } \\
\quad(n 58)\end{array}$ & $\begin{array}{l}P \text { value } \\
(t \text { test })\end{array}$ \\
\hline \multicolumn{5}{|l|}{$\mathrm{Hb}(\mathrm{mg} / \mathrm{dl})$} \\
\hline Mean & $11 \cdot 1$ & $11 \cdot 6$ & $10 \cdot 7$ & \multirow[t]{4}{*}{0.043} \\
\hline SD & $2 \cdot 3$ & 1.9 & $2 \cdot 5$ & \\
\hline$\%>12 \mathrm{mg} / \mathrm{dl}$ & $46 \cdot 5$ & $58 \cdot 5$ & $37 \cdot 9$ & \\
\hline$\%<12 \mathrm{mg} / \mathrm{dl}$ & $51 \cdot 5$ & $39 \cdot 0$ & $60 \cdot 0$ & \\
\hline \multicolumn{5}{|l|}{$\operatorname{TfR}(\mathrm{mg} / \mathrm{l})$} \\
\hline Mean & $6 \cdot 5$ & $5 \cdot 9$ & $7 \cdot 2$ & \multirow[t]{4}{*}{0.062} \\
\hline $\mathrm{SD}$ & $4 \cdot 6$ & $3 \cdot 2$ & $5 \cdot 2$ & \\
\hline$\%>5 \mathrm{mg} / \mathrm{l}$ & $43 \cdot 4$ & $31 \cdot \overline{7}$ & $51 \cdot \overline{7}$ & \\
\hline$\%<5 \mathrm{mg} / \mathrm{dl}$ & $56 \cdot 6$ & $68 \cdot 3$ & $48 \cdot 3$ & \\
\hline \multicolumn{5}{|l|}{ AGP $(g / l)$} \\
\hline Mean & $1 \cdot 0$ & $1 \cdot 0$ & $1 \cdot 0$ & \multirow[t]{4}{*}{0.319} \\
\hline $\mathrm{SD}$ & $0 \cdot 3$ & $0 \cdot 4$ & $0 \cdot 3$ & \\
\hline$\%>1.0 \mathrm{~g} / \mathrm{l}$ & $40 \cdot 0$ & $36 \cdot 6$ & $51 \cdot 7$ & \\
\hline$\%<1.0 \mathrm{~g} / \mathrm{l}$ & $54 \cdot 0$ & $63 \cdot 4$ & $48 \cdot 3$ & \\
\hline \multicolumn{5}{|l|}{ CRP (mg/l) } \\
\hline Mean & $1 \cdot 1$ & $1 \cdot 3$ & $1 \cdot 1$ & \multirow[t]{4}{*}{0.584} \\
\hline $\mathrm{SD}$ & $2 \cdot 0$ & $2 \cdot 2$ & $1 \cdot 7$ & \\
\hline$\%>2.0 \mathrm{mg} / \mathrm{l}$ & $12 \cdot 1$ & $12 \cdot 2$ & $12 \cdot 1$ & \\
\hline$\%<2.0 \mathrm{mg} / \mathrm{l}$ & $87 \cdot 9$ & $87 \cdot 8$ & $87 \cdot 9$ & \\
\hline
\end{tabular}

TfR, transferrin receptor; AGP, $\alpha_{1}$-acid glycoprotein; CRP, C-reactive protein Cut-offs $^{(47)}: \mathrm{Hb}=12 \mathrm{mg} / \mathrm{dl} ; \mathrm{TfR}=5.0 \mathrm{mg} / \mathrm{l} ; \mathrm{AGP}=1.0 \mathrm{~g} / \mathrm{l} ; \mathrm{CRP}=2.0 \mathrm{mg} / \mathrm{l}$.



Fig. 1 Prevalence of various inflammation statuses, based on combined measures of acute-phase proteins, according to settlement status ( $\square$, settled; $\square$, semi-settled; $\square$, total) among pastoral Gabra women of reproductive age, Kalacha Location in Marsabit District, Kenya. Values are means with their $95 \%$ confidence intervals shown by vertical bars

model, only $43 \%$ and $40 \%$ of settled and semi-settled women respectively were Fe replete. About $18 \%$ of settled women compared with $20 \%$ of semi-settled women were in IDE status. Fifteen per cent of settled women compared with $25 \%$ of their semi-settled counterparts were suffering from IDA. ACD was more prevalent in semi-settled women (36\%) than in settled women (24\%), but high in both groups. Overall, among Gabra women, chronic infection appeared to be the leading cause of anaemia followed by Fe deficiency.

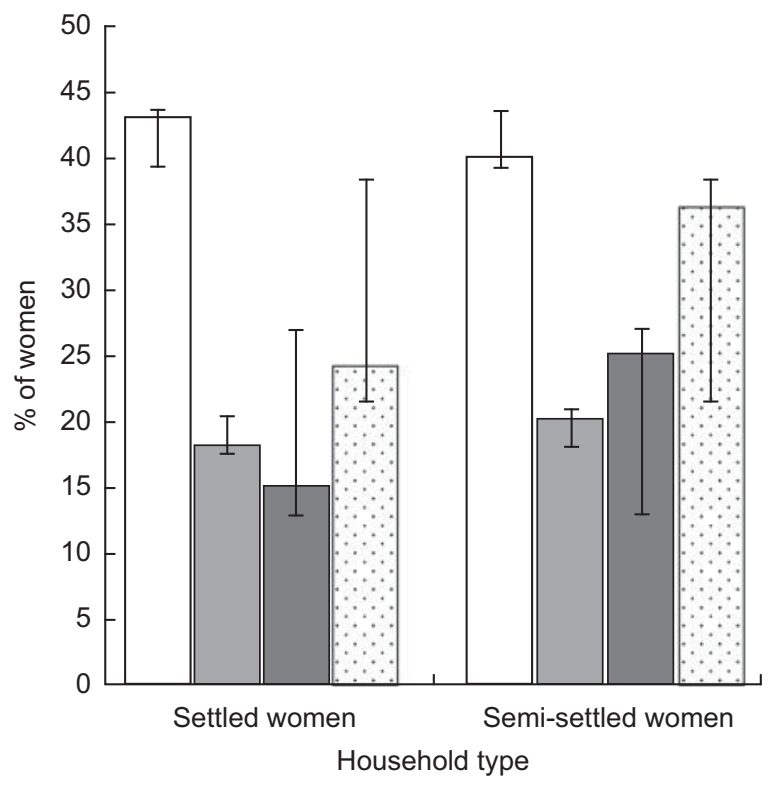

Fig. 2 Prevalences of anaemia ( $\square$, iron replete; $\square$, iron-deficiency erythropoiesis; $\square$, iron-deficiency anaemia; $\square$, anaemia of chronic disease), according to the multiple criteria model, among settled and semi-settled pastoral Gabra women of reproductive age, Kalacha Location in Marsabit District, Kenya. Values are means with their $95 \%$ confidence intervals shown by vertical bars

\section{Discussion}

The purpose of the present study was to examine the effect of settlement on the nutrition and health status of Gabra pastoral women of reproductive age. While most ASAL policies promote settlement of pastoralists as a means of promoting numerous benefits, including 
improved health and nutrition, our study among Gabra women showed that settlement is associated with mixed outcomes and limited improvements. Our study results showed high levels of CED in both communities (49\% among settled and $52 \%$ among semi-settled women), suggesting that food insecurity remains a significant problem. A comprehensive cross-sectional nutrition assessment conducted in Marsabit suggested an alarming malnutrition situation among lactating mothers, with a global acute malnutrition rate of $46 \%$ and a severe wasting rate of $12 \%$, higher than WHO's $15 \%$ emergency threshold ${ }^{(36)}$. The present results also concur with those of the Kenya Demographic and Health Survey, where more than $50 \%$ of women were suffering from CED ${ }^{(11)}$. The $24 \mathrm{~h}$ dietary recalls showed high mean energy intake among Gabra women in both communities, but many did not meet the RNI. The prevalence rates of CED among Gabra women were higher than those found among nomadic and semi-settled Rendille communities in northern Kenya but lower than those of women in India and Ethiopia $^{(9)}$ (Table 2). This may be attributed to still low income levels (Table 1) against high absolute poverty in the area. Currently, the proportion of persons living below the poverty line stands at $80 \%$ in Marsabit County ${ }^{(37)}$.

Semi-settled women had higher rates of micronutrient deficiencies and anaemia than their settled counterparts. Most settled women did not meet their dietary requirements with respect to vitamin A (percentage of adequacy: $0 \cdot 7 \%)$, vitamin C $(2 \cdot 1 \%)$ and $\mathrm{Fe}(10 \cdot 6 \%)$. Most semi-settled women also did not meet their dietary requirements with respect to energy $(16 \cdot 7 \%)$, protein $(32 \cdot 1 \%)$, vitamin $\mathrm{A}$ $(1 \cdot 2 \%)$, vitamin $\mathrm{C}(1 \cdot 2 \%)$ and $\mathrm{Fe}(3 \cdot 6 \%)$. According to Jackson $^{(38)}$, infection can occur in the presence of malnutrition as the primary aetiological factor (e.g. malaria) or as a secondary feature due to nutritionally driven impaired immune response. The leading type of anaemia was ACD, followed by IDA. Only $43 \%$ and $40 \%$ of settled and semisettled women were Fe replete. Infection, in particular chronic infection, was high among Gabra women, and more prevalent in semi-settled (41\%) than settled women (29\%). Based on biochemical analyses of acute-phase proteins, only $59 \%$ of settled and $46 \%$ of semi-settled women were found to be healthy.

For IDE and IDA, one possible cause could be inadequate dietary intake of Fe. A study done by Faruk et al. ${ }^{(39)}$ on urban pregnant Bangladesh women found that low serum vitamin A levels $(<30 \mu \mathrm{g} / \mathrm{dl})$ were associated with lower $\mathrm{Hb}$ levels in women with inadequate intakes compared with those who had adequate intakes. Further, the pregnant women with low serum vitamin A levels had a greater risk $(\mathrm{OR}=1 \cdot 8 ; 95 \% \mathrm{CI} 1 \cdot 2,2 \cdot 8)$ of also being anaemic. With extremely low dietary vitamin A intake, anaemia due to vitamin A deficiency could not be ruled out in the Gabra pastoral population. Dietary Fe deficiency may provoke symptoms of folate deficiency resulting in asystematic progression to megaloblastic anaemia $^{(40)}$. Consumption of vitamin $\mathrm{C}$ together with Fe-rich food sources may enhance absorption of non-haem Fe if taken within an hour of each other. With extremely low vitamin $\mathrm{C}$ intake (Table 2), inadequate absorption of dietary Fe prompting IDE and IDA in the Gabra women cannot be ruled out. Trials conducted in rural Mexican adults dependent on maize and legume diets established, through isotope studies, that consumption of $25 \mathrm{mg}$ of vitamin $\mathrm{C}$ is needed twice daily with meals in order to double $\mathrm{Fe}$ absorption ${ }^{(41)}$. The low observed Fe intake could be attributable to an over-reliance on cereal-based diets (data not shown), where $96 \%$ of the women in both settlements were being provided cereal-based relief food during the time of the present study. Cereals tend to contribute to intake of Fe absorption inhibitors such as phytates, leading to low bioavailable Fe.

The methods adopted in the present study have several advantages. Sample collection was relatively painless and non-invasive. Whole-blood samples did not require processing in the field as DBS samples require no cold chain (refrigeration or freezing) at field level for 4 weeks, hence aiding storage and transport. This was very appropriate in our study where the population was sparsely distributed and there were limited resources available. The method was previously validated in Marsabit among Rendille women and was used in the present study to evaluate biochemical Fe status among the Gabra women.

Some of the limitations of the study should also be considered. The $24 \mathrm{~h}$ dietary recall was taken for $1 \mathrm{~d}$, and may not represent typical intake. Households participating in the food survey may have modified the usual foods in their diet; hence the intake data might not have accurately represented the habitual diet. Prevailing drought and food relief distribution could also have modified diets, as respondents may have equated the study to impending food relief distribution. However, welltrained, local surveyors emphasized the need to maintain usual diets and all of the households in both settlements participated in the food survey. Northern regions of Kenya are subject to extreme seasonality in rainfall and food supplies, and therefore experience seasonality in dietary intake, nutritional status and morbidity ${ }^{(3,42)}$. Future research should therefore monitor the health and nutrition of Gabra women longitudinally. Nevertheless, the present results provide compelling evidence that food insecurity, dietary intake and chronic infection remain pressing health concerns for both settled and semi-settled Gabra women.

\section{Conclusions and recommendations}

The present study has shown that Fe deficiency is occurring in the context of overall dietary inadequacy among pastoralist Gabra women of reproductive age. While settled women had better dietary intake, nutritional 
status and Fe status than semi-settled women, Fe deficiency and ACD were high in both groups. Fe deficiency and CED are also occurring against a high background level of chronic infection. Numerous studies have documented that Fe supplementation in the absence of disease control measures can increase morbidity, particularly from bacterial and protozoal diseases ${ }^{(43-46)}$. Therefore, vertical programmes that address Fe deficiency through means such as supplementation may require additional interventions aimed at strengthening food security and containing infectious disease among pastoral women. Government and development and donor agencies need to be proactive with regard to poor maternal nutrition. The approach needs complex, multifaceted and intersectoral interventions based on long time periods to tackle the wide range of social and environmental determinants of health; a decisive move in this direction may help reduce the poverty and health challenges observed in the present study.

\section{Acknowledgements}

Sources of funding: The study was funded by Kenya Agricultural Research Institute through the World Bankfunded Kenya Agricultural Productivity Project (KARI/ KAPP). Conflicts of interest: No conflicts of interest exist. Authors' contributions: A.O.A. was the lead scientist for the present research; B.S.-D. and J.P.T. were university supervisors during thesis work at Egerton University. All authors have seen and approved the submitted manuscript. Acknowledgements: The authors thank the University of Washington, Seattle for support with blood sample analysis. They also appreciate the support from local leaders and thank the women for their patience and cooperation during administration of the questionnaires.

\section{References}

1. Little PDH, Mahmoud H \& Cappock LD (2001) When deserts flood: risk management and climatic processes among East African pastoralists. Clim Res 19, 149-159.

2. Fratkin EM, Roth EA \& Nathan MA (1999) When nomads settle: the effects of commoditization, nutritional change, and formal education on Ariaal and Rendille pastoralists. Curr Antbropol 40, 729-735.

3. Fujita M, Roth EA, Nathan A et al. (2004) Sedentism, seasonality, and economic status: a multivariate analysis of maternal dietary and health status between pastoral and agricultural Ariaal and Rendille communities in northern Kenya. Am J Phys Anthropol 123, 277-291.

4. Ndambi OA, Hemme T \& Latacz-Lohmana U (2007) Dairying in Africa - status and recent developments. Livestock Res Rural Dev 19, 111.

5. Nyamori B \& Odhiambo W (2002) Food poverty profile for the settled households in pastoral communities: a case of Gabra and Rendille in Marsabit District. In Proceedings of the 8th KARI Biennial Scientific Conference, Nairobi, Kenya, 11-15 November 2002, pp. 385-390. Nairobi: Kenya Agricultural Research Institute.
6. Fratkin EM (2004) Ariaal Pastoralists of Kenya. Studying Pastoralism, Drought and Development in Africa's Arid Lands. Boston, MA: Pearson Education Inc.

7. Food for the Hungry International - Kenya (1998) Development Activity Proposal P.L. 480 Title II. Marsabit, Kenya: FHI-Kenya.

8. Government of Kenya, Ministry of Planning and National Development (2007) The Kenya Vision 2030. Nairobi: Government Printers.

9. Shell-Duncan B \& Yung SA (2004) The maternal depletion transition in northern Kenya: the effect of settlement, development and disparity. Soc Sci Med 58, 2485-2498.

10. Central Bureau of Statistics (Kenya), Ministry of Health (Kenya) \& ORC Macro (2004) Kenya Demographic and Health Survey 2003. Calverton, MD: CBS, MOH and ORC Macro.

11. Kenya National Bureau of Statistics and ICF Macro (2010) Kenya Demographic and Health Survey 2008-09. Calverton, MD: KNBS and ICF Macro.

12. Ministry of Health (1999) Anaemia and the Status of Iron, Vitamin A and Zinc in Kenya. The Kenya National 1999 Micronutrient Survey Report. Nairobi: Government Printers.

13. Merchant K (1994) Maternal nutritional depletion. In Maternal and Child Nutrition, SCN News no. 11, 41-43.

14. Mace R \& Sear R (1996) Maternal mortality in a Kenyan pastoralist population. Int J Gynecol Obstet 54, 137-141.

15. Mugenda OM \& Mugenda GA (1999) Research Methods, Quantitative and Qualitative Approach. Nairobi: Acts Press.

16. Maruapula SD \& Chapman-Novakofski K (2010) Nutrient intake and adequacy of Batswana elderly. Afr J Food Agric Nutr Dev 10, issue 7; available at http://www.ajol.info/ index.php/ajfand/article/view/59025/47332

17. Gibson SR \& Ferguson EL (1999) An Interactive 24-Hour Recall for Assessing the Adequacy of Iron and Zinc Intakes in Developing Countries. Washington, DC: ILSI Press.

18. Erhardt J (2004) Nutrisurvey for Windows. Indonesia: University of Indonesia, SEAMEO-TROPMED.

19. Sehmi JK (1994) National Food Composition Tables and the Planning of Satisfactory Diets in Kenya. Nairobi: Nutrition and Food Contaminants Laboratories, Kenya University.

20. Kigutha HN (1994) Household food security and nutritional status of vulnerable groups in Kenya: a seasonal study among low income smallholder rural households. PhD Thesis, Wageningen University.

21. PATH (1997) Anemia Detection Methods in Low-Resource Settings: A Manual for Health Workers. Seattle, WA: PATH.

22. Ahmed F, Mahmuda I, Sattar A et al. (2003) Anaemia and vitamin A deficiency in poor urban pregnant women of Bangladesh. Asia Pac J Clin Nutr 12, 460-466.

23. Shell-Duncan B \& McDade T (2004) Use of combined measures from capillary blood to assess iron deficiency in rural Kenyan children. $J$ Nutr 134, 384-387.

24. Brindle E, Fujita M, Shofer J et al. (2010) Serum, plasma, and dried blood spot high-sensitivity C-reactive protein enzyme immunoassay for population research. J Immunol Methods 362, 112-120.

25. McDade TW \& Shell-Duncan BK (2002) Whole blood collected on filter paper provides a minimally-invasive method for assessing human transferrin receptor level. J Nutr 132, 3760-3763.

26. Brindle E, Fujita M, O'Connor KA (2006) Serum, plasma, and dried blood spot C-reactive protein enzyme immunoassay for population research. http://csde.washington.edu/ downloads/06-06.pdf (accessed November 2012).

27. Food and Agriculture Organization of the United Nations \& World Health Organization (2002) Human Vitamin and Mineral Requirements. Report of a Joint FAO/WHO Expert Consultation, Bangkok, Thailand. Rome: FAO.

28. World Health Organization (1995) Physical Status: The Use and Interpretation of Anthropometry. Report of a 
WHO Expert Committee. WHO Technical Report Series no. 854. Geneva: WHO.

29. Ferro-Luzzi A, Sette S, Franklin M et al. (1992) A simplified approach of assessing adult chronic energy deficiency. Eur J Clin Nutr 46, 173-186.

30. Geissler C \& Singh M (2011) Iron, meat and health. Nutrients 3, 283-316.

31. Wander K, Shell-Duncan B \& McDade TW (2009) Evaluation of iron deficiency as a nutritional adaptation to infectious disease: an evolutionary medicine perspective. Am J Hum Biol 21, 172-179.

32. Asobayire FS, Adou P, Davidson L et al. (2001) Prevalence of iron deficiency with and without concurrent anaemia in population groups with high prevalences of malaria and other infections: a study in Cote d'Ivoire. Am J Clin Nutr 74, 776-782.

33. Thurnham DI \& Northrop-Clewes C (2007) Infection and aetiology of anaemia. In Nutritional Anaemia, pp. 215-230 [K Kraemer and MB Zimmermann, editors]. Basel: Sight and Life Press.

34. Food and Agriculture Organization of the United Nations (1997) Human Nutrition in the Developing World. Rome: FAO.

35. Food and Agriculture Organization of the United Nations (2006) FAO Statistical Year Book 2005-2006 Vol.2/1 and Vol.2/2. Rome: FAO.

36. Kuria EN (2011) Nutrition Survey - May 2011, Marsabit District, Kenya. Consultancy report submitted to Food for the Hungry Kenya (FHK).

37. Kenya National Bureau of Statistics \& Ministry of Planning and National Development (2007) Economic Survey. Nairobi: Government of Kenya Printers.

38. Jackson AA (2007) Anaemia in severe undernutrition. In Nutritional Anaemia, pp. 215-230 [K Kraemer and MB Zimmermann, editors]. Basel: Sight and Life Press.
39. Faruk A, Ismat M, Abeda S et al. (2003) Anaemia and vitamin A deficiency in poor urban pregnant women of Bangladesh. Asia Pac J Clin Nutr 12, 460-466.

40. Machlin L (1991) Handbook of Vitamins, Second Edition, Revised and Expanded. New York \& Basel: Marcel Dekker Inc.

41. Fernald LCH (2007) Socio-economic status and body mass index in low-income Mexican adults. Soc Sci Med 64, 2030-2042.

42. Shell-Duncan B (1995) Impact of seasonal variation in food availability and disease stress on the health status of nomadic Turkana children: a longitudinal analysis of morbidity, immunity, and nutritional status. Am J Hum Biol 7, 339-355.

43. Shankar A, Goodman S \& Stoltzfus R (1999) Safety of Iron Supplementation Programs in Malaria-endemic Regions. International Nutritional Anemia Consultative Group Consensus Statement. Washington, DC: INACG; available at http://www.idpas.org/pdf/330SafetyOfIron.pdf

44. Oppenheimer SJ (2001) Iron and its relation to immunity and infectious disease. J Nutr 131, 2 Suppl. 2, 616S-635S.

45. Gera T \& Sachdev HPS (2002) Effects of iron supplementation on incidence of infectious illness in children: systematic review. BMJ 325, 1142-1151.

46. Sazawal S, Black RE, Ramsan M et al. (2006) Effects of routine prophylactic supplementation with iron and folic acid on admission to hospital and mortality in preschool children in a high malaria transmission setting: communitybased, randomized, placebo-controlled trial. Lancet 367, 133-143.

47. Shell-Duncan B \& Obiero WO (2000) Child nutrition in the transition from nomadic pastoralism to settled lifestyles: individual, household, and community-level factors. Am J Phys Antbropol 113, 183-200. 